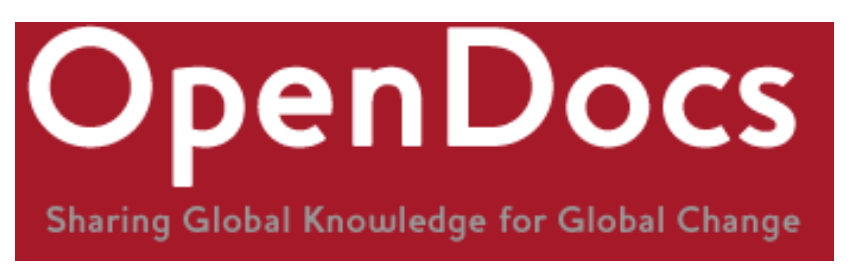

Title: Reducing Risks to Rural Water Security in Africa.

Citation: Carswell, Grace M. and De Neve, Geert (2013) Labouring for global markets: conceptualising labour agency in global production networks. Geoforum, 44 (1), pp. 62-70. DOI: 10.1016/j.geoforum.2012.06.008.

Official URL: http://dx.doi.org/10.1016/j.geoforum.2012.06.008

More details/abstract: This article starts with the recognition that labour has received less than its fair share of empirical and analytical attention in scholarship on global production networks. Little is known about how jobs for export markets fit into workers' wider livelihoods strategies, or how workers react to new employment opportunities available to them. Based on evidence from the Tiruppur garment cluster in Tamil Nadu, South India, the article takes labourers, their livelihoods and their social reproduction as its starting point. It reviews relevant labour geography and GPN literature, and suggests that labour agency has been almost solely conceptualised in terms of collective forms of organised worker resistance. The article then draws on material from South India to examine how people enter garment work as well as the multiple and everyday forms of agency they engage in. We follow a 'horizontal' approach that accounts for gender, age, caste and regional connections in the making and constraining of agency. Such an approach reveals how labour agency is not merely fashioned by vertically linked production networks but as much by social relations and livelihood strategies that are themselves embedded in a wider regional economy and cultural environment. The article argues that labour's multiple and everyday forms of agency not only help to shape local developments of global capitalism but also to produce transformative effects on workers' livelihoods, social relations and reproductive capacities.Version: Accepted Version.

Terms of use: If you publish your article open access, the final published version can be archived in institutional or funder repositories and can be made publicly accessible immediately. The final publication is available at:

http://dx.doi.org/10.1016/i.geoforum.2012.06.008

This is a download from OpenDocs at the Institute of Development Studies

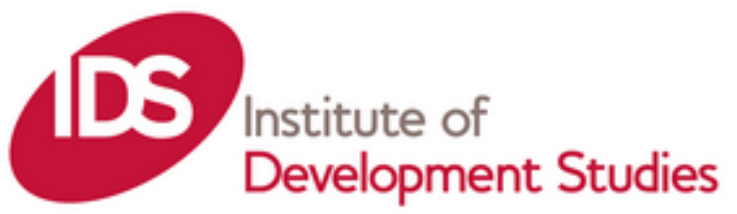




\title{
Labouring for global markets: Conceptualising labour agency in Global Production Networks ${ }^{1}$
}

\begin{abstract}
This article starts with the recognition that labour has received less than its fair share of empirical and analytical attention in scholarship on Global Production Networks (GPNs). Such scholarship often ends with a paragraph on labour, concluding that it is the tail end of the production network that needs further research. Little is known, however, about how jobs for export markets fit into workers wider livelihoods strategies, or how workers react to new employment opportunities available to them. Based on empirical research carried out in the Tiruppur garment cluster in Tamil Nadu, South India, the article takes labourers, their livelihoods and their social reproduction as its starting point.

It first reviews relevant labour geographies and GPN literature, and suggests that labour agency has been almost solely researched and conceptualised in terms of collective forms of organised worker resistance. The article then draws on case material from South India to examine how people enter garment work, the multiple and everyday forms of agency that they engage in, and the effects that their agency has on themselves and the industry. We follow a 'horizontal' approach that accounts for gender, age, caste and regional connections in the making and constraining of agency, Such an approach reveals how labour agency is not merely fashioned by vertically linked production networks but as much by social relations and livelihood strategies that are themselves embedded in a wider regional economy and cultural environment. The article argues that labour's multiple and everyday forms of agency not only help to shape locally specific developments of global capitalism but also produce significant transformative effects on workers' wider livelihoods, social relations and reproductive capacities.
\end{abstract}

Keywords: global production networks, garments, labour agency, gender, caste, Tamil Nadu, India

\section{Introduction}

Labour has received less than its fair share of attention in scholarship on global value chains, and more recently in work on global production networks (Henderson et al, 2002; Coe et al 2004). Articles on governance or labour standards in global production networks typically end with a paragraph on labour, usually concluding that labour employed at the tail end of the network needs further empirical research (Nadvi and

\footnotetext{
${ }^{1}$ This paper is based on joint research carried out as part of an ESRC-DfID funded research project entitled 'Transforming Livelihoods: work, migration and poverty in the Tiruppur garment cluster, India' (RES-167-250296). The research would not have been possible without... [see acknowledgements, separate file]
} 
Thoburn, 2004; Coe, Dicken and Hess, 2008). Nadvi, for example, in a recent assessment of global standards and global governance, calls for research on labour and work processes that engages 'with the local social context - which includes norms and values as well as gender and household relations and the ways in which these impact on local work practices and work organization' (Nadvi, 2008: 340). Such research is needed, he suggests, to make standards more socially embedded and to make compliance with global standards ultimately more effective. More generally, however, we seek to build on Neilson and Prichard's call (2010: 1834) to complement the 'vertical' analyses of trade and production networks with a 'horizontal' approach that explores the role of local factors, such as gender, age and caste, and of regional connections, such as commuting and migration, in the shaping of Global Production Networks (GPN) (see also Leslie and Reimer, 1999). A 'horizontal' approach, we argue, reveals for example how labour agency is not merely fashioned by vertically linked production networks but as much by social relations and livelihood strategies that are themselves embedded in a wider regional economy and cultural environment.

While much of the GPN literature has similarly paid less attention to labour, there is a rapidly expanding body of literature within labour geography that argues for a more committed study of labour and labour agency within the context of global capitalism (Castree, 2007; Lier, 2007; Coe et al, 2008; Coe and Jodhus-Lier, 2010). This scholarship also considers new approaches to the study of labour employed within GPNs, and particularly in the context of neo-liberal labour market restructuring (see e.g. Cumbers et al, 2010). Here, we will not review the labour geography literature in extenso, but draw on some themes and concepts that we find particularly helpful for the ways in which we propose to conceptualise labour, and the study of labour, in the context of a successful South Indian garment manufacturing and export cluster.

It is from the Tiruppur knitwear cluster in Tamil Nadu, South India, which is extensively integrated in global garment production networks, that we draw empirical evidence for the arguments that follow. Fieldwork was carried out in Tiruppur city and its rural hinterland between August 2008 and July 2009. The field research combined a number 
of methods, including in-depth interviews, household and worker surveys, and participant observation. Our informants ranged from factory owners, contractors and supervisors to settled workers, daily commuters and migrants to village high-caste landowners and low caste agricultural labourers.

\section{Conceptualising labour in GPNs}

A central debate within current labour geography relates to labour agency, and to the conceptual and empirical study of labour within the contemporary capitalist economy. In an excellent review article on the place of agency in labour geography, Coe and Jordhus-Lier argue for a re-embedding of labour agency within GPNs, and for a need to 'reconnect conceptions of labour agency into the webs of wider relations with other social actors and institutions in which they [workers] are inevitable embedded' (Coe and Jordhus-Lier, 2010: 11). GPN literature, they aptly point out, 'has remained notably silent on the issue of labour agency. Labour is, most commonly, simply assumed to be an intrinsic part of the production process and workers are typically presented as passive victims of capital's inexorable global search for cheaper wages' (Coe and Jordhus-Lier, 2010: 11). For long, both neo-classical and Marxist economic geography, Lier writes, seemed to depict workers 'as an oppressed class prohibited from actively creating the geographies of capitalism' (2007: 821). What is lacking, therefore, are more refined analyses that recognise the agency of workers, understood by Coe and Jordhus-Lier as 'strategies that shift the capitalist status quo in favour of workers' (2010: 8). This is what labour geography, as the now established sub-discipline within human geography, aims to pursue, and what the GPN literature has begun to recognize.

In this, scholars are responding to Herod's well-known call 'for a much more active conceptualization of workers as engaged in producing the unevenly developed geography of capitalism' (Herod, 2001: 15). While geographers of the capitalist landscape have tended to either ignore the role of labour or merely perceive of it in a passive manner, Herod called for a greater recognition of workers' constant, diverse and manifold attempts 'to shape the landscape of capitalism to their own advantage, in either revolutionary or nonrevolutionary ways (i.e., in ways that may challenge extant 
class relations but also in ways which may reinforce them)' (Herod, 2001: 4). Such an approach, Herod explained, requires radically new ways of conceptualising labour: no longer "merely in terms of "factors" of production or the exchange value of "abstract labour" but to treat working-class people as sentient social beings who both intentionally and unintentionally produce economic geographies through their actions - all the while recognizing that they are constrained (as is capital) in these actions' (ibid: 15). Herod's agenda for a radical re-conceptualisation of labour not only included a focus on workers as actors rather than mere reactors, but also required a more serious attempt to link 'workers' own economic and social practices to the production of their own spatial fixes' (ibid: 31). Or, as Rogaly puts it, 'yes, capital sought its own "spatial fix", but so did labour' (2009: 2). The aim is not to forget about capital altogether, but to reconnect accumulation and the reproduction of capitalism to workers' own practices of survival and social reproduction. We will return to these last points below.

But labour agency has been understood in very particular, and often limited, ways in much of the literature that followed. First of all, much of Herod's own empirical work, and that of most who responded to his initial call, has engaged with a rather narrow concept of labour agency; one which was primarily conceived of in terms of collective, organised labour activism and formally institutionalised trade unions and workers' collectives (Cumbers et al, 2008; Riisgaard, 2009). Lier acknowledges that such a conceptualisation has tended to 'overlook worker agency that is not articulated as collectively organised, political strategies' (2007: 829, italics added). Such a limited focus has itself contributed to the under-theorization of worker agency that labour geographers now seek to redress (Castree, 2007, Coe and Jordhus-Lier, 2010). While this literature has substantially refined our understanding of labour as a collective agent, and of contemporary struggles of unionised activism, the study of labour's multiple agency potential remains underdeveloped. Coe and Jordhus-Lier therefore emphasise the need to 'reveal the variegated landscape for agency potential across different sectors' and the 'massively different levels of potential agency within functionally integrated economic networks' (2010: 11-12). In this paper we seek to contribute to this wider project by focusing on forms of labour agency that are neither collective nor 
formally institutionalised, yet reveal labour's remarkable ability to act and even shape the landscape within which capital operates.

Secondly, the theorization of labour agency has been restricted by an approach that conceives of agency primarily in terms of resistance, rather than in the much broader sense initially argued for by Herod, that is, as the ability to shape the geography of capitalism itself. Or, as Herod put it, agency as the practices (spatial and social) through which 'workers themselves actively make space and shape the economic geography of capitalism in ways not dictated by capital' (Herod, 2001; 31, italics added). Herod in fact conceived of labour agency very broadly, moving away from agency as merely reactive or responsive, i.e. resisting or reshaping the built environments produced by capitalism, and towards a rethinking of workers 'as (pro)active agents actually capable of shaping the built environment themselves as part of the process of their own self-reproduction' (ibid: 29). But given the above-mentioned focus on collective agency, even within the more recent GPN literature, little has remained of this broader and more pro-active view of labour. With the decline of formal trade union activism in the global North and its rapid fragmentation (and subsequent elimination in the global South), there is an overwhelming sense that there is little space left for working class agency under neo-liberal restructuring (Author, dateF, Cumbers et al, 2010). As Cumbers et al point out, 'with a particular time and space contingent form of working class organisation shattered, the implication is that labour (in the broadest sense) has lost the ability to act in its own interest' (Cumbers, 2010: 52). Such a conclusion, however, as Cumbers et al recognise, assumes that organised and collective forms of resistance constitute labour's only 'ability to act'.

In a more promising shift of focus, labour geographers have begun to engage with conceptually more disaggregated concepts of agency, building on Katz's breakdown of agency into acts of resilience, reworking and resistance (Katz, 2004; Cumbers et al, 2010; Coe and Jodhus-Lier, 2010). Katz's aim is precisely to tease apart the many responses to uneven capitalist development and to 'diffuse, if not burst, the romance with "resistance" ...' (Katz, 2004: 241). Seeking to break away from a tradition that 
reads resistance in every autonomous act, Katz distinguishes between social practices 'whose primary effect is autonomous initiative, recuperation, or resilience; those that are attempts to rework oppressive and unequal circumstances; and those that are intended to resist, subvert, or disrupt these conditions of exploitation and oppression' (ibid: 242). Underlying each of these social practices lies a different sort of consciousness. Acts of resilience build on a limited consciousness of the relations of oppression that shape agency, while acts of reworking, and especially those of resistance, draw on and (re)produce a much more critical and oppositional consciousness of the hegemonic powers at work (ibid: 239-259).

Katz's broadening of the concept of resistance reminds us that not all autonomous social practices - be they of individuals or groups - can be interpreted as oppositional acts, even though for the individuals concerned such practices aim to improve or mitigate their circumstances. Her theoretical approach builds on that of Scott (1985), amongst others, by seeking to assess the status of a wide variety of social practices beyond large-scale protests and overt, organised acts of resistance. However, Katz' main critique of Scott lies in her refusal to read resistance in each of such acts and to label them counter-hegemonic (2004: 242). Rather, Katz considers them creative strategies - often even merely tactics (de Certeau, 1984) - through which people live their everyday lives and shape opportunities and possibilities in the face of broader neoliberal transformations. Such a shift away from a resistance-focused approach to labour agency offers a fertile ground for labour geography to refine its conceptualisation of the multiple forms, intentions and effects of agency.

Katz' work provides an invaluable framework to interpret social practices more creatively and to rethink what really counts as resistance, and indeed as forms of agency that are worth considering. However, despite her critique of Scott, Katz herself remains solidly rooted in an approach that sees people's actions as responses to (even though she does not call them all resistance) wider capitalist and neo-liberal transformations rather than as acts that may themselves be constitutive of particular capitalist regimes. The terms reworking, resistance and reformulating suggest 
responsive or reactive modes of agency that act upon existing neo-liberal and capitalist developments. The processes and regimes of the neo-liberal economy are themselves taken for granted, seen as fixed and externally imposed, and above all as unaffected by the practices of labour. Such an approach therefore continues to limit conceptual space for those social practices that contribute to the very shaping of capitalist developments, or, in the words of Herod above, those forms of agency that 'engage in producing the unevenly developed geography of capitalism' (2001: 15). It perceives of capital and labour as reified entities that are merely capable of reacting to each other rather than being mutually constitutive and continually shaping each other. Perhaps a more productive way forward is to view the agency of workers in terms of an ongoing class struggle 'rather than in reified abstractions' (Cumbers et al, 2010: 67) and to 'perceive the agency of capital and labour as bound up in a dialectical totality rather than perceiving capital as the dominant actor over a passive and responsive labour (ibid: 67). It is some of this more interactive role of labour in its relation with capital and in the shaping of labour processes within the South Indian garment production network that we focus on here.

A third limitation of current conceptualisations of labour agency lies in the almost complete absence of attention to individual practices and to everyday and informal practices through which labourers construct their working lives. A stimulating exception to this can be found in Rogaly's recent work (2009), which documents the agency of unorganised temporary migrant agricultural workers in India and the UK. Agency is understood by Rogaly in a broad manner 'as both the intention and the practice of taking action for one's own self-interest or the interest of others', and refers mainly to 'the exercise of agency in spaces of production and especially employment' (2009: 1). Crucially, Rogaly seeks to draw attention to workers' 'everyday micro-struggles over space and time' (ibid: 3), and, in his case, the informal and everyday struggles of often invisible temporary migrant workers. In a re-reading of Harvey's work, Rogaly emphasises that labour's mobility across space is itself a significant form of agency, one which not only offers labour a means to avoid the worst forms of exploitation and access 
to new sources of livelihood, but also one that capital has to reckon with and adjust to (ibid: 3-5).

Evidence from a village in eastern India shows how temporary migration for agricultural work in neighbouring villages gave waged workers a chance to escape local relations of dependency and patronage, and provided them with a degree of empowerment for negotiating the verbal contracts of employment (ibid: 7-8). Moreover, workers' constant search for self-employment - even if only through small, uncertain and risky businesses - reflected their eagerness to escape 'the lower earnings, rudeness and lack of autonomy involved in wage work' (ibid: 9). While acknowledging the hardships suffered by agricultural workers, Rogaly makes the point that these practices are nevertheless forms of agency with significant temporal and well as spatial implications for both labour and capital, and urges labour geographers 'to focus on the low-key and often invisible ways by which people with very limited material means make viable lives' (ibid: 10). We believe that this call is important and take it as a starting point for our own argument. What might appear low-key and invisible from capital's point of view lies in fact at the heart of labourers' everyday lives, considerations and decision-making. Workers' everyday and micro-level practices are replete with agency that has ramifications for the wider structuring of the economy. When a worker decides to migrate or not, to start a garment job or not, or to change factories or not, they are considering their own interests and acting on them, and this agency itself has far-reaching impacts on the organisation of capitalism and its labour processes.

Furthermore, the crucial issue that needs to be re-inserted into these debates is a serious engagement with the sphere of reproduction, and its links with production. The sorts of decisions people make in the arena of employment, as illustrated by Rogaly, are deeply embedded within people's wider livelihood strategies, which in turn are shaped by concerns about the social reproduction of individuals, households and communities. Labour geographers recognise that 'the labour market - the sphere of production - is dependent upon the ways in which workers consume and biologically reproduce, and how they learn, socialise and are being cared for - the sphere of 
reproduction' (Lier, 2007: 817-8). But they have rarely taken this appreciation as the starting point for a study of labour agency, let alone for a study of workers' agency within GPNs. Lier, who in his overview of labour geography recognises the crucial link between the spheres of reproduction and production (as well as capital's limited control over reproductive practices), then continues to dwell exclusively on the role of capital and the state in the formation of local labour markets, remaining silent on the ways in which social reproduction shapes the potential for agency and produces highly gendered labour processes (ibid: 318).

We therefore suggest an approach that starts from the appreciation that workers are embedded in social relations and reproductive activities, and that wider concerns about reproduction, livelihoods and social relations shape - as in both enable and constrain people's decision-making and agency potential. Labour agency, we seek to emphasise, is located both within and outside the sphere of production, and relates to both the material and socio-political spheres of life. While a good deal of workers' agency affects the sphere of production and shapes labour markets and labour processes - as we illustrate below -, much of it also enables significant non-material transformations in wider social relations in which workers are embedded. In the context of the south Indian labour markets that we discuss, labour agency can be found in low-caste workers' struggles to escape dependency on high-caste landowners, in their attempts to gain dignity, and in workers' strategies to retain some control over their time and space at work.

A broad conceptualisation of agency, as firmly embedded in reproductive and social relationships, offers a fruitful framework to both trace the ways in which labour agency shapes the flows, processes and social divisions of work, and to account for agency's wider impacts on livelihoods, social reproduction, and relations of inequality and dependency. To illustrate these arguments we now turn to the Tiruppur garment cluster in South India, where we take labourers employed in the garment industry, as well as those not employed in it (Neilson and Pritchard, 2010), as our starting point. 


\section{The Tiruppur garment industry}

The Tiruppur textile industry is based around the production of readymade knitted garments (eg T-shirts, pyjamas) for both domestic and export markets. Today it is one of the largest knitwear garment manufacturing and export clusters in South Asia, having grown almost without interruption since the early 1970s. Total exports from Tiruppur were valued in 2007 at around \$2 billion, making it an important foreign exchange earner for India. Whilst there are a small number of large, vertically integrated units, employing several thousand workers, most production takes place in non-integrated units. These are small or medium sized, specialise in one or two stages of the production process (e.g. knitting, dyeing, printing, cutting-manufacturing-trimming, etc) and employ between five and a couple of hundred workers.

Across export firms we find a large variety of production regimes, but the main cuttingmanufacturing-trimming (CMT) units can, organisationally, be divided into two broad categories: the large export companies that employ hundreds of garment workers on what resembles the Fordist or Taylorist assembly line, and smaller workshops that employ a variable number of workers producing garments in a flexible manner. The large companies use what is locally referred to as 'the line system' and tend to produce bulk orders. They run fixed shifts, pay a monthly salary based on shift-rates, and register workers as regular employees on a payroll. In the smaller and medium-sized companies, most workers are recruited through labour contractors, have more irregular but also more flexible working hours, and are paid a combination of piece-rates and shift-rates.

Corporate social regulations and international labour standards have also found their way into the industry, but their impact has been limited and varied (Author, DateG). The largest export houses feel the strongest pressure to implement corporate codes of conduct and certified labour standards, and it is these companies that make most efforts to comply with standardised labour regulations (8-hour shifts, shift-rate payments, limited overtime, etc). The smaller and medium sized firms, on the other hand, where the bulk of the workforce is employed, remain much less affected by these regulations. 
These firms employ an ever-increasing part of their workforce through contractors and on a piece-rate basis. As a result, contractors have become key agents within the Tiruppur garment units as they play a central role in both recruitment of labour and management of production of the shop floor (Author, DateE). Here, the labour force is flexibly recruited, with teams of tailors or cutting masters following their contractor from unit to unit in search of new contracts. These teams of workers vary in size and frequently change in composition. While the latter terms of employment offer garment workers a number of advantages (flexibility, autonomy etc.), their downside is a complete lack of job security and the possibility of going without work for days or even weeks at a stretch.

\section{Who works in Tiruppur?}

Who, then, are the workers in the Tiruppur garment industry? Garment workers are certainly not a homogenous or undifferentiated group. Their diversity - in terms of gender, caste, and migratory status - is important for understanding their agency. Here we draw out three broad categories of workers, based on their migratory status: settled workers, commuters, and long-distance migrants. We also look briefly at 'non-garment workers' - those people living in the Tiruppur region who do not work in the industry - in order to better understand who is included and who is excluded from work for this GPN.

Settled workers are those workers who consider themselves settled in Tiruppur, whether they originate from there or not. Many, in fact, are settled migrants, although some do originate from Tiruppur or its close hinterland. Although settled workers may return to their 'native place' for occasional festivals and family functions, they have no plans to return to live there, rarely send money back, and are usually not investing (for example in a house or land) in their 'native place'. Settled workers are typically married men or women, who live as a family unit in rented accommodation. A typical settled worker is Mohan, now in his late twenties, whose father migrated with his family to Tiruppur from Madurai (200km away) in 1997. Already having some tailoring skills Mohan quickly established himself as a singer tailor, working in the export market through different contractors. Sometimes he himself also works as a contractor - 
moving between tailoring work and contracting work at different times. He married a woman from his 'native village', but whose family had also moved to Tiruppur. Living in a rented house in Tiruppur, Mohan returns to Madurai a couple of times a year, but his parents and siblings are also based in Tiruppur. He does not invest 'back home' but invests whatever savings he has from garment work in insurances and savings schemes, and more recently in the private education of his daughter.

In contrast long-distance migrants are labourers who come for periods of several months, often even years, but intend to return home. They send money back regularly and may have come to Tiruppur to meet a particular financial need or repay a debt. Others come following family arguments, or as a result of love affairs. Such migrants are typically young unmarried men or women, who come from across Tamil Nadu. Male long-distance migrants typically live in rented accommodation, often sharing a room with several others, while women migrants typically live in hostels or other accommodation provided by the company. It is of course possible, and not unusual, for a long-distance migrant to become a settled worker over time, depending on how well they do in Tiruppur. Thus a young unmarried man might initially have the intention of returning 'home', but over time he may get married, bring his wife to Tiruppur, and gradually become more settled. A typical long-distance migrant is Lalitha who came to Tiruppur in early 2008 from a village about $300 \mathrm{~km}$ south-east of Tiruppur. Belonging to a poor Dalit family, she wanted to go to Tiruppur but her mother was hesitant. When the thatched roof of their house burnt down and the family urgently needed money, they agreed to let her go. On arriving in Tiruppur, Lalitha, then aged 18, started work as a garment checker and trimmer in a small checking centre where two girls from her home village were already employed. Six months later her younger sister, then aged 16, joined her in the same unit, where they worked alongside eight other young migrant women. The couple who run the checking centre provide them with food and accommodation, and both Lalitha and her sister spoke fondly of their employers and of the care they receive from them. While their original plan was to work to cover the costs of the house repairs, the youngest of the sisters - when interviewed in early 2009 - was keen to stay in Tiruppur and at least part of her earnings are now used to fund their older brother's 
college education. Other young women join larger export houses, where they are accommodated in hostels and paid a monthly salary.

A third group of workers are the commuters who live in the villages around Tiruppur and commute in daily. They may travel up to $50 \mathrm{~km}$ per day, by cycle, motorbike or public transport, or increasingly by 'company vans' provided by their employers to collect them from their village and drop them off each day. Whilst initially commuters were largely from higher castes, over the last 10 to 15 years substantial numbers of Dalits have been able to access garment jobs in town (see also Heyer, 2010). Commuters are mainly men and unmarried women. Few married women commute (see below) but some do because of difficult circumstances at home (such as alcoholic husbands, or being widowed or separated). A typical commuter is Subramanian a 25 year old Dalit who lives in the village of Allapuram, 19km from Tiruppur and works in Tiruppur as a powertable tailor. Landless, like most members of his caste, both his parents work as casual agricultural labourers, but Subramanian's income from garments is now the largest source of income for the household. Subramanian began work as a 'helper' about 5 years ago, learning the skills of tailoring on the shop floor. Still unmarried and living with his parents he gives some of his wages to his parents, spends on clothes and his mobile phone, and has also contributed to improvements to the family house. Subramanian spoke extremely positively about work in Tiruppur, saying that it was easy to get work, that he likes piece rates and that he prefers to move around between companies. Another, rather less typical worker from the same village is Lakshmi, a 37 year old married woman who works as a quality checker in Tiruppur. Her husband is an alcoholic and as their marriage was an inter-caste love marriage they have little family support. Shift work pays her a secure income and allows her to send her daughter to a local Teacher Training College. In addition, Lakshmi runs a small sari-selling business in the village, and relies on her 18 year old daughter to assist with the domestic work.

The final group to be mentioned here are 'non-garment workers' - those people living in the Tiruppur region who do not work in the industry. Although it may seem odd to include non-garment workers we argue that understanding who is not involved in the 
garment industry and the reasons for their non-involvement reveals a great deal about workers' agency (and lack thereof) as well. People are not involved in the garment industry either because they are excluded or because they opt for alternative employment opportunities, such as agricultural work, construction work, etc. Here, we consider three groups of 'non-garment workers' (and there are others not examined), which include certain groups of men, married women and 'older' agricultural labourers.

One group of men and women typically excluded from the Tiruppur garment sector are Dalits living in powerloom villages located in Tiruppur's rural hinterland. In addition to Tiruppur's urban garment industry, a rural textile industry has mushroomed in the region as local landowners set up small powerloom units in villages to the west of Tiruppur from the 1970 s onwards. This rural powerloom industry produces plain woven cloth for further processing, and is very differently structured and organised compared to Tiruppur's garment industry. While powerloom owners depend for labour on both local villagers (many of whom are Dalit) and long-distance migrants, central to their recruitment is the payment of often substantial cash advances through which they seek to 'tie' both male and female workers to their looms. Because of these cash advances, many powerloom workers are now heavily indebted to their employers and so are unable to leave the village for work in Tiruppur. In addition to indebtedness, Dalit powerloom workers also suffer from continued caste discrimination in the village: the continued separation of drinking cups in village workplaces and exclusion from the village temple (Author, DateB). Furthermore, opportunities for 'career progression' are limited in powerloom work, whereas villagers perceive the Tiruppur garment industry as the place where 'anyone can make it big'.

A second group of 'non-garment workers' are married women living in the commuter belt around Tiruppur. Working hours in Tiruppur are long: a typical working day is a socalled 'shift and a half' (that is 12 hours) although longer working days are not uncommon. For married women - especially once they have children -these hours, on top of commuting, make it very difficult to work in Tiruppur whilst maintaining domestic responsibilities. For this reason many women drop out of garment work on having their 
first child. Some (depending on their contacts) manage to continue with home-based garment work, such as garment checking and labelling, but others return to casual agricultural work. A third group of 'non-garment workers' are those who are considered (or consider themselves) to be too old for garment work. These may be as young as in their 30s, but believe themselves to be too old to learn. For Dalits this may be as much about feelings of low self-esteem coming out of generations of subordination or about being unable to afford the lower wages that they would earn as a helper in garment work, rather than anything to do with their actual age or ability. For others, the fact that sons or daughters start to earn an income means they have less need to go to work, and thus withdraw from Tiruppur.

\section{Agency, livelihoods and social reproduction}

What agency, then, do these different groups of workers have, and what makes for agency in the first place? In answering this question, we start from the recognition that everyday, low-key and often hardly visible practices and choices made by individuals constitute significant forms of agency (Rogaly, 2009: 10). It is through such practices that labourers, who are in many ways restricted by a lack of material, social and human capital, turn things to their advantage and make the best of the options available to them. Through such micro-agency workers have an impact on the labour regimes that emerge within the industry and improve aspects of their own livelihoods, social reproduction, and social relations. We therefore begin by considering some of the things that different workers want throughout their lives, and the choices and decisions they make as they strive to achieve these. These are decisions around whether to come to Tiruppur, whether to stay, and the decisions they make once in Tiruppur. Faced with a particular set of opportunities and constraints, they weigh up these choices, alongside other livelihood options. The decisions that they take affect the labour regimes that emerge within the industry and shape capital's response in its attempt to capture and retain workers.

Different workers want different things at different times in their working lives. Thus, young, unmarried, long-distance male migrants may want to earn as much as possible 
in a short space of time. To that aim, they like overtime and, as they develop their skills, prefer to be paid piece rates, and so actively seek work in units that offer these options. Thus, larger compliant firms paying fixed monthly salaries, with little or no overtime (as promoted by corporate codes and international labour standards) do not suit them. Instead, these workers are more likely to follow a contractor who moves between smaller firms and pays piece rates, in the full knowledge that at times they will be asked to work double shifts and sometimes more. Such a pattern suits single migrant men with few responsibilities in Tiruppur but with the desire to earn well and send money home, or settled workers whose domestic circumstances allow them to work long days.

Similarly, an unmarried woman migrant might also come to Tiruppur seeking to earn a reasonable amount of money in a short space of time. But once in Tiruppur a woman's opportunities are structured by a set of gendered norms that constrain her spatial mobility within the town and the industry. Unlike men, she will be expected to live in accommodation seen as 'secure' and 'safe' by her own family in order to maintain cultural norms of respectability. She is, therefore, likely to either live in a hostel provided by a larger company, or with the owner's family if she works in a smaller unit. Furthermore, unlike men, she will not be able to move freely between factories around town and will not have the flexibility and freedom to pick those factories that offer the best terms and conditions. Women's restricted spatial mobility means, therefore, that they are more likely to accept a smaller (but more secure) income, rather than a more lucrative job that requires them to be spatially mobile. Gendered constraints both shape and restrict women's agency.

While wanting to earn as much as possible, others factors are important for workers as well, such as flexibility, autonomy and dignity. Many workers, for example, want flexible labour arrangements that allow them to take days off to attend family functions or deal with domestic duties. To achieve this flexibility workers chose to work through contractors, which gives them more room to negotiate flexible working hours as well as higher pay (Author, dateE). For the same reason, men in particular seek to work for contractors and at piece-rates whenever possible, as this offers them a degree of 
freedom and control over their own working time and work rhythm that they do not avail of under shift-rate regimes (Author, dateD). While several sections of the industry have a long history of piece-rate payments (Chari, 2004), other sections have moved to piece-rates more recently in response to workers' requests.

Powertable tailors, for example, always used to be paid by the shift but in 2008-9 we observed a shift towards piece-rates in the small garment unit we were studying. In late 2008 all powertable tailors in this unit were paid on a shift-rate basis, but in May 2009 three tailors left the powertable contractor and moved to another contractor from whom they demanded piece rates. Two of the replacement tailors whom the contractor recruited for his team also asked for piece rates, and the contractor agreed, knowing that this was the only way to hold on to skilled tailors. Skilled powertable tailors know they can earn more on piece-rates and increasingly press contractors for this type of payment. The contractor confirmed that this was a fairly recent but rapidly spreading development in the industry. For the tailors, this shift was not merely about being able to make more money from a day's work but also about having more control over their work rhythm: on piece-rates, men can start and stop work as they like, take breaks when it suits them and negotiate a day off with the contractor if needed. Men value this autonomy at work highly and often contrast working for a contractor with employment in large export companies, which they describe as tedious with its routines driven by the clock - 'you have to sit in your seat all day long!'.

Similarly, a woman settled-worker, married with young children, needs flexible working arrangements and will therefore seek employment where she can stop work to collect water when the municipal taps are switched on, or to collect her children from school. She may therefore prefer home-based work, such as 'trimming' or 'checking', which is paid piece-rates, and can be fitted in around her domestic responsibilities. Alternatively, she may seek work as a checker or a helper in a company but through a contractor, typically a male kin member such as a brother or husband. This gives her more space to negotiate working hours than if she was to work fixed shifts for a factory owner. Women's work preferences obviously change with their lifecycle. For example, after the 
birth of the first child, women typically withdraw from the labour force for several years. Once their children begin school many return to work, but often in lower status (and lower paid) jobs - for example, as checkers or helpers, in order to obtain the flexibility they need for their domestic responsibilities: flexibility thus comes at a cost. Very often this also means a shift from export to domestic garment work, or from factory work to home-based work, and from large compliant firms to smaller, more local firms. Whilst large compliant firms are insistent on fixed shift times and regular attendance (see below), smaller non-compliant firms located within women's neighbourhoods offer them spatial and temporal flexibilities that allow women to combine paid work with domestic responsibilities. While women make choices, their agency clearly cannot simply be read as empowerment: for men flexibility is associated with high pay and long working days while for women it is associated with low pay and part-time work.

It is not only women whose preferences change during their lifecycle, but other workers' too. For example, at certain times in their lives people may value greater security above income or flexibility, and therefore be willing to accept lower but less risky or fluctuating incomes. To achieve security workers may move into the domestic sector, characterised by more regular and predictable flows of work, or to large compliant firms with set shifts and monthly wages. Such compliant factories have notably less overtime, and employees are registered on a regular payroll. Those who opt for more regular but usually less well paid work include, amongst others, older men and women who may be less keen to work long days or at the higher speed that piece-rates entails.

Often, decisions about whether to work or not, and under what conditions, are made as part of a wider household strategy. For example, households might seek to pursue an overall income stream that balances the highly fluctuating, but more rewarding, incomes of household members working on piece-rates (for example, unmarried sons) with the regular and more secure income of other household members working on shift rates (typically mothers and fathers, and married women). Another group that might prioritise security over income are widowed or divorced women, who are the sole earners in the household, especially when they have dependents such as older parents or children 
who can help them with their domestic responsibilities. Rather than to pursue the highest income potential, they seek a secure income stream and avoid jobs that risk leaving them without income for days at a stretch. Such women workers, like Lakshmi above, avoid work for a contractor and prefer direct employment by a firm paying fixed shift rates. They often end up as checkers or helpers in smaller units, or as tailors in the domestic sector or larger export firms.

In addition to a search for incomes and security, workers' search for employment in Tiruppur and their decisions to commute or migrate in the first place, are also informed by a strong desire for independence and dignity. Across Tamil Nadu - and India as a whole - landless Dalits continue to work as poorly paid casual agricultural labourers. Not only is pay low and work seasonal, but Dalits are routinely stigmatised and discriminated against by their employers, and so they are keen to escape localised relations of dependency and patronage (Rogaly, 2009). For many of them, the very act of migrating or commuting is a means of escaping rural ties, gaining a sense of dignity, and achieving a degree of economic and social independence (Rogaly 2009, Author, DateC). Moving to Tiruppur, where no-one knows their caste, and where, in the words of Suresh, a Dalit man employed in Tiruppur, 'employers look to the talent, not at the caste', is a major step to achieving this independence. Again and again people living in the villages outside Tiruppur told us that, in contrast to their own villages 'in Tiruppur there is no jati (caste) problem'. And the evidence is that many Dalits are successfully employed in Tiruppur: $20 \%$ of our Tiruppur worker survey ${ }^{2}$ were Dalits, while $45 \%$ of households from a Christian Dalit community in a village $19 \mathrm{~km}$ from Tiruppur had their primary (and a further 10\% their secondary) source of income from the garment industry, with $61 \%$ of households having an individual working in the industry ${ }^{3}$. People from this community told us repeatedly that work in Tiruppur provided them with hitherto undreamt of opportunities and in doing so transformed relations between castes and rural patron-client relationships. These changes relate to their ability to earn

\footnotetext{
${ }^{2}$ This survey was of 300 workers, selected from across the industry. It aimed to cover all parts of the industry, and workers were purposively selected to reflect this.

${ }^{3}$ This survey was undertaken of all 251 households living in the village of Allapuram, of whom 23\% were Adi Dravida Christians.
} 
independently from the high caste village landowners, to invest in education of children, and to considerably improve their housing and overall living standards.

However, as mentioned above, other Dalits are unable to escape rural ties of dependency and patronage. Powerloom workers (one of the non-garment worker groups) living in villages near Tiruppur are tied to their employers through a system of advances, and although they can move within the powerloom industry, they struggle to leave it altogether (Author, dateB). For them the opportunities offered by the Tiruppur garment industry remain out of reach, as they do for many agricultural labourers and construction workers who have not been able to make it to Tiruppur, be it because of age, gender, distance or other constraining factors.

\section{Agency and the shaping of the Tiruppur garment industry}

How then does agency, and the decisions that garment workers make at different times in their life, shape the industry? Here we briefly discuss three ways in which different types of workers' agency affect labour processes in the garment industry.

Firstly, the multiple decisions and strategies taken by different groups of workers from diverse backgrounds at different points in their life, has produced a hugely diverse, mobile and fluctuating labour force for Tiruppur's industrialists. This workforce is, from the factory owners' perspective, 'slippery' or elusive, moving constantly from contractor to contractor, and factory to factory on an almost weekly basis. Factories that attempt to employ their workforce on a regular payroll face high levels of absenteeism and labour turnover. It is the diverse agency of workers that has created a highly mobile labour force and it is capital that has to respond to it, as it attempts to capture and control workers (see below).

Secondly, different groups of workers make different demands that fashion the labour processes within the industry. For example, the attempts of some workers (e.g. power table tailors) to earn as much as possible has fed the demand for piece rates across several sections of the industry. Similarly, many workers' desire for higher incomes 
means they actively seek factories where overtime is possible, while at other times in their life course, workers may avoid more taxing and high-speed jobs. The desire for flexible work arrangements, which fit with other responsibilities, leads many garment workers to prefer employment through labour contractors (over direct employment in a company). The combined effect of workers' multiple demands is that companies trying to employ their entire workforce as regular employees (on fixed shifts) struggle to recruit and retain enough workers. As a result they are forced to use a variety of recruitment strategies, and end up handing over a good deal of labour management to labour contractors.

Thirdly, gendered norms and responsibilities also shape the supply of labour to the garment industry. Women's agency is embedded in, and structured by wider social norms and gender relations: their decisions to participate in the industry (and on what terms) are not merely structured by the demands of capital, but by the demands of society. Women's agency is structured by their domestic responsibilities and by considerations of respectability. Whereas women might work as tailors before marriage, for example, many return later in lower status jobs, which give them the flexibility they need. Thus lower paid jobs end up being dominated by women, whereas the better paid tailoring jobs, especially in smaller units, are predominantly taken by men. It is the same gendered norms that supply large numbers of young unmarried female migrants, with no domestic responsibilities within Tiruppur, to the larger units which have 'safe' hostels and where they can maintain expectations of respectability.

Moreover, the decisions and opportunities of some workers also structure and determine the opportunities of others. Settled workers, for example, are well connected within Tiruppur and so are able to monopolise the best jobs. Less attractive, 'dirtier' and less well paid jobs are left to poorly informed and new-to-town long-distance migrants, many of whom are Dalits. Arriving in town with few contacts and skills, these workers are willing to take up dirty jobs such as those in the dyeing sector that are shunned by settled workers and anyone with better skills. This partly explains why certain types of workers work in certain types of units. 


\section{Capital responding?}

But labour, obviously, is not the only agent within the industry, capital strategises too. Capital's agency is, in part at least, in response to ever-changing supplies and demands of labour, as it struggles to accommodate and control an elusive labour force. Capital also struggles to accommodate the vagaries of fluctuating product markets and the associated problems of maintaining the 'right' labour force. This recalls Cumber's point that the agency of capital and labour are 'bound up in a dialectical totality' (Cumbers et al, 2010: 67), and we need to perceive the relationship between them as a two-way, iterative interaction in which they continually shape each other: capital responds to labour's agency and labour to capital's strategies.

Factory owners try to reduce absenteeism and high labour turnover through a range of strategies. Firstly, they attempt to reduce worker mobility by paying bonuses at the festival of Diwali, the amount of which is determined by the number of shifts worked. These bonuses can amount to about a month's salary and many workers also receive gifts from their employers. This strategy allows employers to retain workers up until the time of Diwali, but after that companies usually face high labour turnover as workers decide whether to continue in the same company or search for a new company that suits them better.

Secondly, some factory owners try to retain their workforce over longer periods of time by providing on-site accommodation, despite the added costs of investment. Larger factories build hostels for migrant workers, while smaller units offer rooms for young unmarried migrants. This particularly suits, and is in response to, the gendered needs of unmarried migrant women.

Thirdly, in order to access a wide pool of commuters, many larger companies provide company vans to collect and drop workers from surrounding villages. Some units have gone further by relocating their factories to villages in Tiruppur's rural hinterland. For 
example, Millennium Apparels built a factory close to a village $8 \mathrm{~km}$ from Tiruppur from where they hoped to recruit the bulk of their labour force. For this company the decision has been broadly successful and a large number of its workforce now comes from the village itself. It has not, however, solved the problem of absenteeism, which the owners consider to be the main obstacle to improving productivity. However, the strategy of relocation is not always straightforward. Muthusamy, owner of Revathi Apparels, similarly relocated his company to the outskirts of Tiruppur, but found himself unable to recruit workers there, as the area he chose was neither close to a village nor the town. He had to relocate back to a site closer to Tiruppur where he hoped to be better able to recruit workers. Other employers try to retain labour by providing continuous work and pay even when the market is slack. They may only be able to offer half days' work instead of full employment, but it might prevent workers from leaving the company altogether when product orders are down over a period of days or weeks.

Another response, discussed above, is capital's increasing reliance on contractors for the recruitment and management of labour on the shop floor. Here companies face opposing pressures. Codes of conduct and labour standards, compliance with which is increasingly demanded by western buyers, require companies to standardise working hours and provide the workforce with regular contracts. On the other hand, the challenge of managing a diverse and mobile labour force and fluctuating markets pushes them towards the casualisation of labour through the use of contractors. The result is that capital tries different strategies to recruit and retain labour, resulting in a diversity of labour regimes across the industry, and indeed even within one factory. Part of the workforce may be directly employed by the company while others may be recruited and managed by labour contractors

\section{Conclusion}

This paper has engaged with the agency of workers involved in or affected by the Tiruppur garment industry in South India, an urban industrial cluster which is wellintegrated into the global garment production network. In contrast to approaches that focus on collective and organised acts of resistance, we have zoomed in on those 
practices and forms of agency that are rooted in people's everyday decision-making around employment, livelihoods, social reproduction and social relations. Decisions to work in Tiruppur or not, for how long and under what conditions are forms of agency that shape workers' everyday lives and social reproduction, as well as the industry itself. It helps garment workers to make ends meet, to improve their working conditions, and at times - even to mitigate forms of oppression and exploitation that shape their everyday lives. Labour's agency and choices shape the supplies of labour into the industry, the modes of labour recruitment, systems of payment and forms of work organisation. High levels of absenteeism and high levels of labour turnover, for example, are a recurrent issue for large export houses who try to comply with global labour standards. They also affect companies' recruitment strategies by making them take recourse to labour contractors or relocate into villages where they can tap into rural labour markets with fewer alternatives.

In taking this approach, we have built on Cumbers et al who argue for 'a perspective that integrates processes of capitalist production and social reproduction as a social totality, emphasising how labour agency and resistance necessarily take place both within and outside the workplace' (2010: 48). We have also taken a 'horizontal approach' (see Nielson and Pritchard, 2010), by looking beyond the factory and the industry into people's everyday lives. Work for global markets involves forms of agency and impact that straddle factory and home, urban and rural, and industrial and agricultural.

However, it remains important to point out that not all practices have the same intentionality or effect, and much agency remains shaped by structural constraints that impose real barriers to the transformative capacity of labour agency. Returning to Katz (2004), some workers' practices can best be seen as mere 'resilience', such as when women workers seek to simply 'get by' by taking a lower paid job in a domestic factory or opting for a job near to their residence. Such decisions are expressions of agency as workers make choices that are clearly in their own interests, but the transformative potential of such agency is heavily curtailed by structural constraints of gender, age and 
caste. Other decisions taken by workers are part of their attempts at 'reworking' the conditions under which they labour. Here, tailors' deliberate demands for piece-rates instead of shift-rates or workers' preference to work for a contractor rather than as a company employee form strategies through which garment workers seek to improve their working conditions or, at least, regain some control over their working space and time. While workers may not get the best terms and conditions of employment, they have their ways of getting the terms and conditions that suit them best. Yet such agency is rarely progressive or transformative: it does not challenge the basic status quo between capital and labour within the industry. In fact, workers' focus on particular interests and individualised tactics is precisely what curbs their ability to engage in collective action contributing to the decline of trade union activity in the cluster (Author, DateF).

Other practices, however, are more progressive, especially when we consider the effects of garment workers' agency outside the workplace and beyond the sphere of employment. Dalit commuters' access to urban garment work and incomes, for example, while initially perhaps an expression of mere resilience to make ends meet, has produced more far-reaching transformations in their rural livelihoods and social relations back in the village (Author, dateC, Heyer, 2010). It has allowed many to settle debts, invest in houses and education and - above all - escape dependencies on powerful landowners who used to rule their everyday working lives. Away from the high-caste landlords, Tiruppur offers low-caste commuters and migrants the opportunity to build independent livelihoods, away from the ties of rural capital, and also provides them with the economic independence necessary to transform rural social relations and inequalities. Here we find evidence of a much more transformative effect of worker agency. While its impacts on shop floor working conditions may be limited, workers' very access to urban, industrial employment has the effect of disrupting historically entrenched rural relations of dependency and discrimination. Unfortunately, however, not everyone in Tiruppur's hinterland benefits in the same way: women remain much more heavily dependent on agricultural work, older villagers are less likely to be able to commute to town than younger ones, Dalits remain less well connected to the urban 
industry than higher caste villagers, and especially those rural dwellers employed in the village-based powerlooms remain bonded through debt to Gounder capitalists and continue to suffer persistent discrimination and oppression (Author, dateA).

In this article we have sought to move away from a narrow conceptualisation of labour agency as either a form of resistance or empowerment, to one that recognises the varied acts through which workers employed in GPNs create manageable working lives and dignified livelihoods for themselves. This labour agency is obviously constrained not only by the agency of capital and the broader class struggle that shapes its politics, but also - and importantly so - by gendered norms, roles and responsibilities, by relations of caste and dependency, and by broader concerns of social reproduction in labourers' home locations. We therefore argue for a conceptualisation of labour agency within GPNs that considers the full range of sources and impacts of agency, and that straddles the spheres of production and reproduction, factory and home, urban and rural. Gender, caste, life-cycle and mobility are all instrumental in determining the parameters of workers' participation in global market production and the transformative potential engendered by their agency.

\section{REFERENCES}

AuthorC. Not working for export markets: work, agency and livelihoods in the Tiruppur textile region. (Paper presented at Sussex Workshop, July 2010).

AuthorA. T-shirts and Tumblers: caste, politics and industrial work in Tiruppur's textile belt, Tamilnadu. Contributions to Indian Sociology.

AuthorB. From field to factory: Tracing bonded labour in the Coimbatore powerloom industry, Tamil Nadu. Economy and Society.

Castree, N.. 2007. Labour Geography: A Work in Progress. International Journal of Urban and Regional Research 31(4): 853-62.

Chari, S., 2004. Fraternal Capital: peasant-workers, self-made men and globalization in provincial India. Stanford University Press, Stanford.

Coe, N., Dicken P., Hess, M., 2008. Global production networks: realizing the potential. Journal of Economic Geography 8(3): 271-295.

Coe, N., Hess, M., Yeung, H.W-C., Yeung, O., Dicken, P., Henderson, P., 2004. Globalizing regional development: a global production networks perspective. Transactions of the Institute of British Geographers NS 29, 468-84.

Coe, N., Jordhus-Lier, D., 2010. Constrained agency? Re-evaluating the geographies of labour. Progress in Human Geography 1-23 (Published online on 23 April 2010).

Cumbers, A., Nativel, C., Routledge P., 2008. Labour agency and union positionalities in global production networks. Journal of Economic Geography 8, 369-387. 
Cumbers, A., Helms, G., Swanson, K., 2010. Class, agency and resistance in the old industrial city. Antipode 42, 46-73.

de Certeau, M., 1984. The Practice of Everyday Life. University of California Press, Berkley.

Author, DateF 2008. Global Garment Chains, Local Labour Activism: New Challenges to Trade Unionism and NGO Activism in the Tiruppur Garment Cluster, South India. In: De Neve, G., et al (Eds.) Hidden Hands in the Market: Ethnographies of Fair Trade, Ethical Consumption and Corporate Social Responsibility. Research in Economic Anthropology, 28: $213-40$.

Author,DateG., 2009. Power, Inequality and Corporate Social Responsibility: The Politics of Ethical Compliance in the South Indian Garment Industry. Economic \& Political Weekly XLIV(22): 63-71.

Author, DateD. There you are like a bird in a cage!: Indian garment workers critiquing Fordism and CSR. (Paper presented at the BASAS Conference, University of Warwick, April 2010).

Author, DateE. Of Contractors Old and New: Trajectories and Roles of Labour Contractors in the Tiruppur Garment Industry. (Paper presented at Sussex Workshop, July 2010).

Henderson, J., et al. 2002. Global production networks and the analysis of economic development. Review of International Political Economy 9(3): 436-464.

Herod, A., 2001. Labor geographies: workers and the landscapes of capitalism. New York: Guildford Press.

Heyer, J., 2010. The impact of 'Tiruppur' on the hinterland: gender, caste and age. (Paper presented at Sussex Workshop, July 2010).

Katz, C., 2004. Growing up global: economic restructuring and children's everyday lives. Minneapolis, MN: University of Minnesota Press.

Leslie, D. and S. Reimer. 1999. Spatializing commodity chains. Progress in Human Geography 23 (3): 401-420.

Lier, D.C., 2007. Places of Work, Scales of organising: A review of labour geography. Geography Compass 1(4): 814-33.

Nadvi, K., 2008. Global standards, global governance and the organization of global value chains. Journal of Economic Geography 8(3): 323-343.

Nadvi, K., Thoburn, J.T., 2004. Vietnam in the global garment and textile value chain: impacts on firms and workers. Journal of International Development 16(1): 111-123.

Nielson, J. and B. Pritchard. 2010. Fairness and ethicality in their place: the regional dynamics of fair trade and ethical sourcing agendas in the plantation districts of South India. Environment and Planning A 42: 1833-1851.

Riisgaard, L., 2009. Global Value Chains, Labor Organization and Private Social Standards: Lessons from East African Cut Flower Industries. World Development 37(2): 326-340.

Rogaly, B., 2009. Spaces of work and everyday life: labour geographies and the agency of unorganised temporary migrant workers. Geography Compass 3: 1-13.

Scott, J.C., 1985. Weapons of the Weak: Everyday forms of peasant resistance. Yale University Press, New Haven. 